\title{
THE ORIGIINS OF THE SPECIAL OLYMPICS MOVEMENT IN POLAND IN THE 20TH CENTURY
}

\author{
Dorota Pilecka, A, B, D, E Tomasz Jurek ${ }^{A, D}$ \\ University School of Physical Education in Poznań \\ Faculty of Physical Culture in Gorzów Wielkopolski

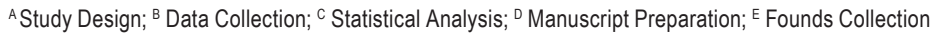 \\ Address for correspondence: \\ Dorota Pilecka \\ Faculty of Physical Culture \\ Estkowskiego 13, 66-400 Gorzów Wlkp., Poland \\ E-mail: d.pilecka@awf-gorzow.home.pl
}

\begin{abstract}
Ahstract Since World War II, sport involving people with disabilities has gradually evolved in Poland, and people with intellectual disabilities had not participated in any sporting events until the end of the 1960s. They were treated as second-class citizens having no rights that they should be entitled to. The reason behind this was the State's policy towards sport, where highperformance sport, especially Olympic sport, played a vital role that was supposed to testify to the high level of civilisation in communist Poland. People with disabilities were regarded as a shameful problem and were practically kept hidden away. They, therefore, did not participate in social life, including athletic activities. The first competition held in Poland under the name of the Special Olympics was not organised until 1969 in Poznań. On May 26, 1973, the first national sporting event for mentally retarded children (as they were referred to at the time) was called Spartakiad and was held in Warsaw. That was around that time that the sports movement in Poland began to draw on American practices, and in the 1980s it adopted the form of the Special Olympics, both in terms of organisation and sporting activities. This period was marked by active cooperation with the USA and other countries, where Polish athletes with intellectual disabilities began to compete in international competitions.
\end{abstract}

Key wordls Special Olympics, sport by people with disabilities, Paralympic Games

\section{Introduction}

The authors of this paper discuss the origins and evolution of sports involving people with intellectual disabilities in the second half of the $20^{\text {th }}$ century in Poland, as well as outline the process of emancipation of people with disabilities in sport until they could finally join the Special Olympics International competition in the 1980s. The basic research method used in writing this paper was an analysis of historical sources. The methods of induction and deduction have also been applied.

The evolution of sports involving people with intellectual disabilities in Poland has not yet been separately addressed in academic literature, representing a significant gap in the historiography of physical culture. The only 
writings that have been published so far are various personal accounts of parents of children with disabilities, and of some activists working for the advancement of physical activity in the community of people with disabilities. Against this backdrop, literature on the Paralympic movement looks much more impressive. Therefore, it is worth presenting the beginnings of this specific area of sporting activity involving people who were initially described as mentally ill or mentally impaired. It is important to note that over the centuries, people with intellectual disabilities have come a long way towards being accepted, to be seen within the bounds of normality and actively involved in sport. They have come a long way, from a long period of physical elimination, exclusion and isolation, through a time of contempt and humiliation, stigmatisation and denigration, indifference, even heartlessness, as they were confined inside the walls of closed institutions. In a number of societies, families did not always create much of a friendly environment for their loved ones affected by this type of disability. It was not until the 20th century that dignity was restored to this group of people and their full rights began to be recognised. People with intellectual disabilities were not able to fully enjoy their fundamental human rights because of the many barriers, restrictions and discriminations they were faced with over the course of history. Many of these rights have been regulated and included in international legal acts, such as; the United Nations Universal Declaration of Human Rights of $10^{\text {th }}$ December 1948; the United Nations Declaration on the Rights of Mentally Retarded Persons adopted by General Assembly resolution 2856 (XXVI) of 20 th December 1971; the United Nations Declaration on the Rights of Disabled Persons adopted by the United Nations General Assembly on $9^{\text {th }}$ December 1975 (Resolution 3447); the Standard Rules for the Equalization of Opportunities of Persons with Disabilities adopted at the $48^{\text {th }}$ session of the United Nations General Assembly on 20 $0^{\text {th }}$ December 1993; the European Charter of Sport for All: Disabled Persons. The Convention on the Rights of Persons with Disabilities was adopted by the United Nations General Assembly in 2006.

\section{The troubled opigins of sport involving people with intellectual disabilities in Poland}

Since 1945, sports involving people with disabilities have gradually evolved in Poland, however, those with intellectual disabilities did not initially participate in any sporting events. For these people, sport has long been an inaccessible form of activity. One such reason for this was the fact that the authorities considered these people to be an embarrassing problem and not worthy of any priority. As a rule, the parents remained alone at home with their disabled children, deprived of any support, as well as therapy or therapeutic treatment. Moreover, the evolution of the athletic movement was dominated by a high-performance trend, treated as propaganda for the promotion of Poland across the world. What mattered most was Olympic medals, while physical recreation and rehabilitation remained a secondary concern. Nevertheless, the first instances of physical activity involving people with disabilities began to be seen (Tracewski, 2009). Since 1952, the only organisation involved in physical recreation, tourism and high-performance sport for the disabled has been Zrzeszenie Sportowe "Start" ["Start" Sports Association]. Their activities were exclusively aimed at people with disabilities employed by Spółdzielnie Inwalidów [Cooperatives of the Disabled]. It was not until 1961 that the Association of Cooperatives of the Disabled and the "Start" Sports Association of Work Cooperatives initiated a systematic process of development of sport, tourism and recreation by organising sports clubs at every cooperative for the disabled. At that time, the "Start" Sports Association established a system of competitions organised at local, regional and national levels, national championships, tournaments, as well as a national games for the disabled every four years (Jandziś, Migała, 2015). People with intellectual disabilities attended camps and participated in rehabilitation stays or afternoon gymnastics 
classes. A huge role in the advancement of sports involving people with disabilities was played by a group of parents of children with disabilities brought together in Towarzystwo Przyjaciół Dzieci [Children's Friends Society]. As part of the activities aimed at supporting their children's development, they explored new forms of activity, such as activities performed in physical education classes. A particularly active involvement in this area could be observed among parents of children with disabilities living in the cities of Warsaw, Poznań and Szczecin (Archive of New Files, 2/1588/0).

Initially, the cities of Poznań and Warsaw were the most prominent centres for the advancement of sport for people with intellectual disabilities, and that was where the idea to organise local competitions and later national tournaments was born. The first competition held in Poland under the name of Special Olympics was organised in 1969 in Poznań. The organisation of the event was initiated by Krystyna Kortus, Wojciech Mazur and Barnard Wieczorek. The national competition was held under the auspices of the "Start" Sports Association and five sports disciplines were represented: track and field, swimming, football, basketball and kayaking. Disabled athletes participating in the event came from all the provinces of Poland. The organisation of the event was modelled on the concept of the Olympic Games for people with disabilities, so there was an Olympic ceremony and a medal table for each province. A genuine competitive spirit could be felt during the event (Kowalik, Miotk-Mrozowska, 2013).

On 26 May 1973, the first national sporting event for mentally retarded children (as they were referred to at the time) was held in Warsaw. The organisation of the event that was called the First Spartakiad of Schools of Life Skills was initiated by Warszawskie Koło Pomocy Dzieciom Specjalnej Troski [Warsaw Aid Group to Support Children with Special Needs], also several schools of life skills from Warsaw, as well as the "Elektra" Cooperative of the Disabled. The event was attended by 211 athletes. The competition was held under the auspices of the School Superintendent's Office for the Capital City of Warsaw, the School Inspectorate for the District of WarszawaŚródmieście, the Board of Directors of the Children's Friends Society the Committee to Support Children with Special Needs, and the District Association of Cooperatives of the Disabled. The program of the event included an opening ceremony parade of the attendees, athletic competitions, announcement of the scores, a prize-giving ceremony and closing. The event hosted in the Warsaw sports hall "Gwardia" is regarded as the first national sporting event for people with intellectual disabilities in Poland (File Depot of the Special School Complex No. 85 in Warsaw, the 1963/1964 School Yearbook of the Eunice Kennedy Special Primary School No. 243; Damentko, 1988).

In the period 1975 to 1980 , a series of events called the Warsaw Special Schools Spartakiad was organised in the region of Warsaw. The venue for the $2^{\text {nd }}$ Warsaw Spartakiad of Schools of Life Skills was held in April 1978 at the Palace of Culture and Science in Warsaw. The $4^{\text {th }}$ Warsaw Spartakiad of Schools of Life Skills was organised in the Capital City Sports Centre in Warsaw. In addition to diplomas awarded to students for their individual performances, depending on the results of the general classification, the schools received financial prizes for the purchase of sports equipment. The $5^{\text {th }}$ Warsaw Spartakiad of Special Schools was held in the "Agrykola" stadium in Warsaw and was attended by the representatives of the Ministry of Schooling and Education, the School Superintendent's Office and the Departments of Schooling and Education. In 1980, over 800 students from 20 special primary schools and 8 special vocational schools were involved in athletic competition. The athletes participated in a lively parade, played a football match, and competed against each other in competitions such as dodgeball, basketball, table tennis and volleyball, football and children's tetrathlon. At the end, the winners were presented with prizes, diplomas and souvenir badges (Czerniecka, 1981). 
In 1975, the city of Poznan hosted the First National Sports Games of the Disabled Youth. The event was attended by 114 representatives from such cities as Białystok, Katowice, Lublin, Olsztyn, Opole, Rzeszów, Warsaw, Wrocław and Zielona Góra. The aim of the competition was to review or evaluate the physical condition of people with intellectual disabilities. Other objectives included social integration and assessment of the relevance of holding these types of competitions as well as the selection of competitors. The organisers also wanted to verify the validity of the rules regulating the competition as these rules had been established with no experience to draw on and without any model rules that could serve as an example. The program of the Games included the following sports: swimming: 50 m, 25 m freestyle and 4x25 m relay; track and field events: a $100 \mathrm{~m}$ run, long jump, baseball throw, triathlon, women's 4x100 m relay and men's 4×200 m relay; an obstacle course where the athletes had to navigate vertical poles spaced out in a trail, go under hurdles, slip their whole body through a sash or a loop band, do a forward roll on a mat, and go past the finish line running; and a tug of war (rope-pulling) for 5-person teams (Dłużewska, Wieczorek, 1976).

\section{Main hubs of sporting activity involving people with intellectual disabilitites in Poland}

Apart from the cities of Poznań and Warsaw, favourable conditions for young athletes with intellectual disabilities to compete against each other were also created in the province of Opole. Students and graduates of Zakład Wychowawczy [Educational Institution] and three other special educational centres from this region competed against each other during sporting events called Spartakiads that were organised for several years. The representatives of school sports clubs from all these facilities participated in team competitions playing football, handball and volleyball. Track and field events were in turn for the athletes to compete individually. Each sporting event had an official character. It started with a ceremonial opening and was attended by many invited guests. The winners received cups, diplomas, pennants, as well as individual certificates attesting to their performance (Ciaciura, 1980). Athletic competitions for children with intellectual disabilities were also organised in the province of Konin. In 1977, the $1^{\text {st }}$ Sports Competition of Special Schools was held in Czepów. The competition was organised in May for five years in succession and was attended by representatives of six special schools (with about 130 athletes participating). The event was organised in the park adjoining the school which had been equipped with long jump pits and high jump stands, 60 - and 100-meter running tracks, as well as handball and football pitches. The event was supported by the School Superintendent's Office, the Board of Directors of the regional branch of the School Sports Association and the Board of Directors of the regional branch of the Children's Friends Society (Jabłoński, 1982). Sport games were also held in the province of Olsztyn where children and young people with intellectual disabilities were given the opportunity to present their skills, improve their ability to work in a team, and compete in the spirit of sportsmanship (Rawa, 1985).

The idea to organise regional Spartakiads for children with intellectual disabilities was put into practice at a fairly early stage in the province of Szczecin. In 1979, the Spartakiad of schools of life skills was held on the premises of one of the educational institutions located in Policka street in Szczecin. The competition was attended by children from the primary school located in Strzałkowska street and the Special Educational Centres in Tanowo and Chojna. The competition included track and field events (a long jump, a $20 \mathrm{~m}$ run, a $100 \mathrm{~m}$ run, ball throw) and a deck tennis ring toss. The idea of hosting sporting events using the available facilities required the management and teachers of a number of schools to restore their pitches, gyms, running tracks and other sports amenities to the required condition. Special educational centres were housed in school buildings (the most popular, almost 
identical schools which were erected to commemorate the millennium of the Polish state) so there were sports grounds in place but in a very poor state of repair. These actions were backed by school principals who got involved in preparing their students for sports competitions. It was also recognised that physical culture played an important role in the education and rehabilitation of children with intellectual disabilities. Physical activity and regular exercises contributed to stimulating and improving the physical condition of mentally impaired children. In 1982, in cooperation with the parents of intellectually disabled children that had been brought together in the Aid Group to Support Children with Special Needs affiliated with the Children's Friends Society, another Spartakiad was organised in the stadium of the School Sports Association. The event was attended by seven teams, and apart from the students and children from the Aid Group to Support Children with Special Needs, the residents of two care homes joined in. Shortly afterwards, when the idea of the Special Olympics began to gain a foothold in Poland, with students from Szczecin's schools who continued their physical training gradually becoming involved in these activities. The competitions were held on a year-round basis bringing together students from various educational institutions, competing in such sports disciplines as football, table tennis and badminton. These activities were concluded with the Special Olympic games organised in the stadium featuring the typical Olympic symbols and rituals such as lighting the flame, performance of the national anthem and hoisting of the country's flag (Pyszkowski, 2018).

The town of Zakopane has also grown to be an important centre of the movement. The activities of the Aid Group to Support Children with Special Needs were conducted there by Andrzej Sekuradzki and his wife Barbara. Initially, a kindergarten was opened, then a rehabilitation and educational centre, and in the years that followed, an occupational therapy workshop. There were also attempts made at the advancement of physical activity involving people with intellectual disabilities (Abramowska, 2012).

\section{The Special Olympics movement is launched in Poland}

In Poland, many initiatives were taken at local and national levels, however, the introduction of unified rules of competition, the organisation of sport competitions, evaluation of results, and awarding athletes with prizes required some outside inspiration and application of external standards or practices. The School of Life Skills in Warsaw at Elektoralna 12/14 was repeatedly visited by guests from the United States who shared their observations and comments. The collaboration with the United States would flourish also thanks to research conducted by Professor Ignacy Wald. Poland was also visited by representatives from France and Austria. The parents of children with intellectual disabilities who were part of the Committee to Support Children with Special Needs worked to establish contacts with organisations from France and Belgium (File Depot of Polskie Stowarzyszenie na rzecz Osób z Niepełnosprawnością Intelektualna [Polish Association for Persons with Intellectual Disability], International materials). Thanks to their active involvement in the international community and the information available to the Polish communities abroad, the news about their sports activities made its way to the Special Olympics Board of Directors in the USA (Tyczyński, 1999).

The first time Poland came into contact with the idea of the Special Olympics was in 1970, when Zenon Jaszczur, who was preparing his doctoral dissertation, contacted Eunice Kennedy-Shriver. He was invited to set up and further develop the Special Olympics movement in Poland. However, he failed to receive any approval from the Polish Ministry of Education (Jaszczur, 2019). In the early 1980s, Leszek Kołakowski maintained contact with Eunice Kennedy-Shriver and Sargent Shriver, but at that time Kołakowski worked and resided in the United Kingdom, and his trips to the United States were mainly to give lectures at the Kennedy Institute of Ethics (National 
Library, Manuscript Collection, 1971-1980). Krystyna Mrugalska remarked that her first meeting with Eunice Kennedy-Shriver took place in Warsaw during the latter's visit to Poland's capital city at the turn of 1979 and 1980. It was also then that Frank Hayden visited Warsaw and voiced his encouragement for Poland to join the Special Olympics (Mrugalska, 2018). For the first two years, the matters in question were handled by the Secretary of the Committee to Support Children with Special Needs (KPDST). Since 1979, the KPDST was chaired by Professor Jerzy Doerffer from Gdańsk who could speak English and who had some international experience. However, he had no time to deal directly with the Special Olympics within the Committee to Support Children with Special Needs (Doerffer, 2005; Maszczak, 1994; Krukowska, Maszczak, 1989; Cwojdzińska, 2018).

The founder of the Special Olympics movement, Eunice Kennedy Shriver, sent an invitation to the President of the Children's Friends Society for the Polish delegation to attend the 1983 Baton Rouge World Summer Special Olympics in the United States (Krukowska, Maszczak, 1989). The financial support to buy sportswear for the first athletes was provided by private individuals, e.g. Krystyna Mrugalska bought tracksuits and sports shoes. At that time, there were no systemic solutions or methods to raise funds for the purchase of equipment for the athletes. The costs of air travel and their stay were covered by the Special Olympics International. The Polish team that went to Baton Rouge, Louisiana included four athletes supported by K. Dzikowski as the team's medical doctor and J. Doerffer as the team's coordinator and interpreter. The Polish team and the team from Cuba were the only ones from communist bloc countries. The Polish team's coordinator was invited to the meetings of the Organizing Committee, which took place during the $6^{\text {th }}$ Special Olympics World Summer Games. In October 1983, J. Doerffer accepted the offer to participate in the activities of the International Board of Special Olympics. It was an extraordinary honour for Professor J. Doerffer to join the Board of Special Olympics International. He saw that as an opportunity to gain insight into the ways to introduce and popularise sport among people with intellectual disabilities, as well as to obtain expert support and some funding from the organisation. He received copies of instruction manuals and official competition rules from Washington. At that time, he enlisted the cooperation of Jerzy Tyczyński, who in turn engaged some specialists from the University of Physical Education in Warsaw. The press release that appeared in the Washington Post in 1987 read: "Another board member from a communist country is professor Jerzy Doerffer, a Pole and former president of the Technical University of Gdansk. He has a retarded child and helped bring the Special Olympics into Poland" (McCarthy, 1987).

As the need to explore and further develop new directions of activity had been identified by the Committee to Support Children with Special Needs, in particular the application of ideas and activities promoted by the Special Olympics International in Poland, a split or division emerged within the Committee, followed by the formation of an independent organisation. As a result of the situation at hand, in February 1985 the Polish Committee of Special Olympics was established which was attached to the General Board of the Children's Friends Society. The creator and founder of the committee, as well as the honorary president of the Special Olympics Poland Association, established in the years that followed, was Dr. Jerzy Tyczyński. He himself was a father of a disabled child so his personal commitment certainly played an important role in the process of advancing the idea of Special Olympics in Poland. At the same time, Jerzy Tyczyński was first an active member of the Polish Association for Persons with Intellectual Disability, and in the years 1967 to 1979 he was the Chairman of the Board of the Warsaw branch of the association. He was inspired, among other things, by the swimming skills of Z. Dzierzbicka's daughter that he had the chance to watch during the summer camps, and made efforts to put a programme of swimming classes in place for people with intellectual disabilities living in Warsaw (Dzierzbicka, 2018). 


\section{Conclusions}

The main objectives of the Special Olympics Committee were to provide those people with intellectual disabilities with access to sporting activities and to organise competitions that were in line with the principles and spirit of the global Special Olympics movement. Other goals were to promote physical culture among people with intellectual disabilities and to advance the global Special Olympics movement (Maszczak, 1994). The members of the Committee were the parents of children with disabilities: Wanda Bargielewicz, Michał Glajzer, Barbara Jaskierska, Andrzej Sekuradzki, Henryk Kudła, social activists from the sports community: Janusz Romanowicz, Jacek Żemantowski, activists working in government departments and agencies that supported children with disabilities: Wiesława Jelska, Daniela Mroczek. From that moment on, sport involving people with intellectual disabilities began to take off in Poland. Official sports rules, instructions, textbooks and training manuals were sent from Washington to be much welcomed in Polish special schools, schools of life skills, educational centres, residential care homes, and regional centres helping people with intellectual disabilities (Tyczyński, 1999). The establishment of a countrywide organisation operating as part of the wider international initiative put an end to the pioneering phase of the development of sport involving people with intellectual disabilities in Poland. As it was aptly summarised: "The Special Olympics movement very quickly earned the support of education and sports authorities and the hearts of influential figures from the world of politics, business and from the artistic circles. As a result, the Special Olympics movement quickly gained a foothold in Poland" (Zuber, Cieszewska, 2003).

It can be stated that the origins of sport involving people with intellectual disabilities in Poland date back to the 1960s. A significant role in the advancement of Special Olympics was initially played by the Children's Friends Society and the "Start" Sports Association. The activities undertaken by groups of parents of disabled children, who initiated and co-organized many sports competitions, proved a vital role in the advancement of disabled sports. In the 1980s, relations were established with the Special Olympics International in the USA, from where organisational and financial support was obtained. As a result, an opportunity emerged to join the international competition as part of the Special Olympics in 1983.

\section{References}

Abramowska, B.A. (2012). Taka dobra historia... Czterdzieści lat działań rodziców na rzecz osób z niepełnosprawnością intelektualną. Warszawa: Polish Association for Persons with Intellectual Disability.

Archive of New Files (Archiwum Akt Nowych), 2/1588/0, Spółdzielcze Zrzeszenie Sportowe START w Warszawie, Series: 4 Spis zdawczo-odbiorczy No. 10. Dział Wychowania Fizycznego i Sportu Inwalidzkiego, 10/37, Informacja o X-letniej działalności Zrzeszenia Sportowego „Start” w zakresie wychowania fizycznego i sportu wśród inwalidów.

Biuletyn Informacyjny - Rehabilitacja Zawodowa Inwalidów, 46 (1976).

Ciaciura, M. (1980). Kronika. Szkoła Specjalna, 4.

Czerniecka, J. (1981). Kronika. Szkoła Specjalna, 1.

Damentko, M. (1988). Olimpiady specjalne szansą dla osób upośledzonych umysłowo. Kultura Fizyczna, 11-12.

Dłużewska, W., Wieczorek, B. (1976). I Ogólnopolskie Igrzyska Młodzieży Upośledzonej Umysłowo. Poznań.

Doerffer, J.W. (2005). Życie i pasje. Wspomnienia, volume III. Burzliwy okres 1970-1988. Gdańsk: Foundation for the Promotion of the Shipbuilding Industry and Maritime Economy.

Jabłoński, M. (1982). Sport dla wszystkich. Szkoła Specjalna, 3, 224.

Jandziś, S., Migała, M. (2015). Rys historyczny rozwoju rehabilitacji w Polsce i na świecie. Opole: Silesian Institute.

Kowalik, S., Miotk-Mrozowska, M. (2013). Sport paraolimpijski, a rozwój osób niepełnosprawnych. In: M. Wilski, J. Gabryelski (eds), Idee olimpijskie a kierunki rozwoju sportu osób niepełnosprawnych. Poznań: University of Physical Education. 
Krukowska, A., Maszczak, T. (1989). Ruch olimpiad specjalnych w Polsce. Wychowanie Fizyczne i Zdrowotne, 1.

Maszczak T. (1994). Special Olympics jako nowe zjawisko w światowym sporcie. In: M. Barlak (ed.), Personalistyczna wizja sportu. Warszawa: Salesian Publishing House.

McCarthy, C. (1987). The Olympiad of Courage. The Washington Post, 2.08.1987.

National Library, Manuscript Collection, Leszek Kołakowski's correspondence, The Joseph P. Kennedy, Jr. Foundation, Washington (signed by: John C. Raines, Sargent Shriver, Eunice Kennedy-Shriver) 1971-1980, pp. 2-8.

Rawa, D. (1985). Szkolnictwo specjalne w województwie olsztyńskim. Szkoła Specjalna, 4-5.

Cwojdzińska, J. (2018). Oral report - 20.06.2018.

Dzierzbicka, Z. (2018). Oral report - 13.09.2018.

Jaszczur, Z. (2019). Oral report-03.01.2019.

Mrugalska, K. (2018). Oral report - 11.12.2018.

Pyszkowski, Z. (2018). Oral report - 29.08.2018.

File Depot of the Polish Association for Persons with Intellectual Disability, International materials.

File Depot of the Special School Complex No. 85 in Warsaw, 1963/1964 School Yearbook.

File Depot of the Special Educational institution in Tanowo, School Yearbook „Sport”.

Tracewski, B. (2009). Przyjaciele dzieci. Warszawa: Children's Friends Society - General Board.

Tyczyński, J. (1999). Początki Olimpiad Specjalnych w Polsce. Biuletyn Informacyjny Olimpiad Specjalnych Polska Jeżyk, 27.

Zuber, A., Cieszewska, B. (2003). Olimpiady Specjalne szansą dla upośledzonych umysłowo. In: W. Mynarski, J. Ślężyński (eds), Efekty kształcenia i wychowania w kulturze fizycznej. Katowice: University of Physical Education.

Cite this article aS: Pilecka, D., Jurek, T. (2020). The Origins of the Special Olympics Movement in Poland in the 20th Century. Central European Journal of Sport Sciences and Medicine, 4 (32), 43-50. DOI: 10.18276/cej.2020.4-04. 